\section{Pengaruh regulasi emosi kognitif terhadap depresi pada mahasiswa tingkat akhir dimasa pandemi covid-19}

\author{
Vira Qoyyum Maslita ${ }^{1}$, Putri Saraswati ${ }^{2}$, dan Udi Rosida Hijrianti ${ }^{3}$ \\ Vira Qoyyum Maslita', Putri Saraswati' , dan Udi Rosida Hijrianti
}

\author{
$\Psi$ Cognicia \\ p-ISSN 2746-8976; e-ISSN 2685-8428 \\ ejournal.umm.ac.id/index.php/cognicia \\ 2021, Vol 9(2):76-84 \\ DOI:10.22219/cognicia.v9i2.18023 \\ (C)The Author(s) 2021 \\ ()ㅇㅇㅇㅇ 4.0 International license
}

\begin{abstract}
The COVID-19 pandemic has affected people's mental health, especially in the education sector. One of the mental health problems that often occur in students who are completing their final assignments are symptoms of depression. Cognitive emotion regulation is one capacity to overcome depression with the use of adaptive approach. The purpose of this study was to determine the effect of cognitive emotion regulation on depression in final year students in Indonesia during the covid-19 pandemic. This study uses a quantitative approach. The research subjects were 349 final year students and their data were taken using an accidental sampling technique. Analysis of research data used the simple linear regression test. The results showed that there was a significant influence between cognitive emotion regulation and depression $(p=0.00)$. The effect of cognitive emotion regulation shown is $4.2 \%$ of the variance of depression.
\end{abstract}

\title{
Keywords
}

Cognitive emotion regulation, college students, covid-19, depression, final assignment

\section{Pendahuluan}

Kegiatan menjaga kesehatan mental perlu dilakukan untuk menghindari masalah psikologis yang menghambat interaksi dengan orang lain dan selalu semangat dalam mencapai target hidup, maupun melakukan kegiatan seharihari. Sayangnya masalah psikologis yang dihadapi dimasa pandemi covid-19 merupakan sesuatu yang tidak bisa dihindari dengan mudah jika tidak adanya dukungan, pengendalian lingkungan maupun emosi diri sendiri untuk lebih kuat menghadapi situasi saat ini. Pengaruh covid-19 menyebabkan seluruh lapisan masyarakat mengalami kerugian baik bidang ekonomi, sosial, kesehatan, politik, dan salah satunya berimbas pada bidang pendidikan terutama para pelajar dalam penyerapan materi pembelajaran secara online maupun mandir, serta kesehatan mental mereka untuk menjalani aktivitas sehari-hari dengan produktif.

Produktivitas keseharian yang cukup pada individu dipengaruhi oleh mental yang sehat. Hal ini dipertegas dengan pernyataan bahwa kesehatan mental merupakan kondisi psikologis individu yang memiliki kesadaran dan kemampuan untuk menangani stress, menyelesaikan permasalahan tanpa merugikan pihak lain dan diri sendiri, melakukan kegiatan sehari-hari secara efisien dan produktif, mampu berkontribusi dalam lingkungan kerja maupun sosial individu tersebut menurut WHO (Herman \& Jané-Llopis (2005). Perilaku keseharian individu baik dalam usaha untuk merawat diri sendiri maupun merespon lingkungan sekitar dapat menggambarkan kondisi kesehatan mental, hal ini didukung oleh penelitian
Hanaysha (2016) yang menyatakan jika individu belajar untuk melatih perkembangan kognitif dan afeksi, individu tersebut akan cenderung produktif pada aspek kehidupannya termasuk dalam kegiatan berorganisasi.

Kesehatan mental yang kurang stabil dapat dipengaruhi dari kecemasan dan ketakutan (Rejo et al., 2020). Ketakutan dapat diserap dari suatu perbuatan individu terhadap suatu peristiwa maupun ketakutan pada kondisi yang dilalui masyarakat semacam bencana alam maupun bencana buatan. Berkaitan dengan rasa takut terhadap kondisi bencana, belakangan ini terdapat permasalahan yang menjadi sorotan mulai bulan Februari 2020 hingga saat ini yaitu peristiwa pandemi covid-19. Pandemi menurut dunia kesehatan merupakan wabah suatu penyakit yang menyerang orang dalam skala besar di berbagai negara (Munadliroh \& Faizah, 2020). Covid-19 merupakan penyakit yang menyerang saluran pernafasan manusia yang bilamana tidak ditangani langsung menyebabkan kerusakan serta kesulitan menyuplai oksigen, jika tidak mendapatkan oksigen dan menurunnya imun tubuh, serta terdapat penyakit penyerta seperti komplikasi akan menyebabkan kematian.

\footnotetext{
1,2,3 Universitas Muhammadiyah Malang, Indonesia
}

Korespondensi:

Vira Qoyyum Maslita, Fakultas Psikologi Universitas Muhammadiyah Malang

Email:viramaslita@gmail.com 
Pandemi covid-19 tidak hanya menyebabkan gangguan pada kesehatan fisik saja. Pandemi juga mempengaruhi kesehatan mental banyak orang, baik pengidap covid maupun masyarakat. Menurut Tian et al. (2020) pada masa pandemi ini menyebabkan gangguan obsessive compulsive, interpersonal sensitivity, kecemasan fobia, dan nafsu makan yang buruk karena berbagai ketidakpastian dari virus korona baru. Kekhawatiran semakin membesar karena masyarakat menelan segala informasi dari segala sumber tanpa adanya screening yang didukung dari penelitian Gao et al. (2020) menyatakan bahwa informasi palsu sosial media menyebabkan peningkatan kecemasan bersamaan depresi sehingga perlunya memerangi "infodemik" dengan cara pemantauan dan menyaring informasi palsu. Pernyataan dari kedua sumber yaitu Tian et al. (2020) dan Gao et al. (2020) berkaitan dengan gangguan mood, gangguan tidur, kelelahan, dan gangguan regulasi diri (Moreno et al., 2020). Selanjutnya hasil penelitian di Indonesia yang dilakukan oleh Prayogi et al. (2020) menyatakan salah satu dampak pandemi yang menyebabkan mahasiswa Universitas Airlangga menjadi depresi yaitu penerapan work from home sehingga menjadi terhambatnya aktivitas sosial khususnya berkaitan dengan bahan pembelajaran. Berdasarkan hasil penelitianpenelitian yang telah dituliskan menyebutkan adanya pengaruh yang dirasakan masyarakat baik kesehatan fisik maupun mental. Pada masalah kesehatan mental banyak yang mengalami kecemasan maupun depresi.

Depresi merupakan salah satu gangguan yang ditandai dengan penurunan suasana hati yang disebabkan oleh berbagai faktor. Berdasarkan Radloff (1977) depresi berkaitan dengan gejala-gejala suasana hati tertekan, perasaan bersalah, perasaan tidak berharga, perasaan tidak berdaya, keputusasaan, keterbelakangan psikomotorik, kehilangan nafsu makan, dan gangguan tidur. Terdapat dua faktor yang mempengaruhi depresi menurut Kring et al. (2013) yaitu faktor psikologis dan faktor sosial. Faktor psikologis merupakan salah satu faktor yang mempengaruhi tinggi rendahnya kesehatan mental karena dipengaruhi oleh neuroticism ketika menanggapi permasalahan yang diakibatkan dari diri sendiri maupun kejadian di luar kendali individu tersebut.

Depresi merupakan gangguan kesehatan mental yang menjadi perhatian karena mencapai $62 \%$ yang mengalaminya (PDSKJI.org., 2020). Berdasarkan analisis data swaperiksa PDSKJI (Perhimpunan dokter spesialis kedokteran jiwa Indonesia) dimasa pandemi covid-19 menyatakan bahwa terdapat dua kelompok usia yang mengalami depresi yaitu kelompok usia 17-29 tahun sebesar 66,3\% dan kelompok usia di atas 60 tahun sebanyak 68,9\%. Peningkatan masalah psikologis ini terjadi pada bulan April 2020 sebesar 50\% dan Agustus 2020 sebesar 48. Analisis data swaperiksa PDSKJI menyatakan bahwa 1 dari 5 orang memiliki pemikiran tentang "lebih baik mati", $62 \%$ masalah psikologis depresi, serta $44 \%$ berpikiran "lebih baik mati dan self injury" (PDSKJI.org., 2020).
Hasil penelitian terkait dampak pandemic yang dilakukan oleh Santoso et al. (2020) dari 148 mahasiswa usia 18 hingga 20 tahun terdapat 52,7\% normal, 25,7\% mengalami gangguan mood ringan, dan mencapai batas depresi 12,2\%. Selanjutnya penelitian Prayogi et al. (2020) mendapatkan data usia 22-23 mengalami depresi sedang sebesar 22,46\%, usia 20-21 tahun mengalami depresi tinggi sejumlah 57,22\% dibandingkan usia 18-19 tahun yang mengalami depresi paling rendah sejumlah $20,32 \%$. Hal ini berbeda dengan penelitian depresi sebelum adanya pandemi seperti yang dilakukan oleh Kurniati et al. (2017) yang meneliti kesesuaian aplikasi depresi tertera hanya 3 orang yang mengalami depresi berat dari 25 orang, sisanya 11 orang normal dan 11 orang depresi ringan. Berdasarkan data sebelum pandemi menggambarkan bahwa sedikit yang mengalami depresi dibandingkan saat masa pandemi.

Menurut Santrock (2002) rentang perkembangan dewasa awal dimulai pada akhir usia belasan tahun atau awal usia dua puluhan dan berakhir diusia tiga puluhan. Jika dikaitkan dengan pernyataan usia dewasa awal, maka mahasiswa akhir masuk pada kriteria usia dewasa awal diantara akhir belasan dan diawal dua puluhan. Menurut Siswoyo (2007) definisi mahasiswa merupakan individu yang sedang mempelajari suatu ilmu di perguruan tinggi negeri, swasta, serta lembaga yang memiliki tingkatan yang sama dengan perguruan tinggi. Mahasiswa memerlukan adanya kemampuan mengolah dan mengendalikan untuk tetap berfikir stabil dalam menghadapi permasalahan baik akademik maupun non akademik. Jika tidak mampu mengatasi permasalahan akademik, maka akan berpengaruh dalam kesehatan mental seperti stres, cemas, atau timbul depresi. Untuk mencegah stress, cemas, serta depresi diperlukan regulasi emosi kognitif seperti pendapat Joorman \& Gotlib (2010) yang menyatakan bahwa depresi dipengaruhi oleh penggunaan regulasi emosi kognitif dan diberbagai aspek yang digunakan.

Rodriguez et al. (2020) menemukan bahwa strategi regulasi emosi kognitif menghasilkan lebih banyak pengurangan depresi untuk individu yang terikat dengan cemas. Pengendalian emosi tidak hanya berfokus dalam diri, namun pengendalian emosi perlu adanya faktor sosial sebagai pendukung untuk mengevaluasi diri ke arah positif seperti pernyataan Doré et al. (2017) Pelatihan berorientasi sosial dalam regulasi emosi, kognitif, perilaku dan menyarankan bahwa dengan membantu orang lain untuk mengatur akan meningkatkan keterampilan mengendalikan dan kesejahteraan emosional diri sendiri.

Hasil penelitian depresi dan regulasi emosi yang dilakukan oleh Joorman \& Gotlib (2010) menemukan bahwa depresi dipengaruhi oleh penggunaan regulasi emosi baik kognitif maupun perilaku yang digunakan. Pada penelitian Farahdika \& Listiyandini (2018) menemukan bahwa dimensi cognitive reappraisal dan expressive suppression tidak berperan secara signifikan terhadap depresi remaja yang memiliki orangtua bercerai. 
Farahdika \& Listiyandini (2018) menduga adanya faktor lain yang lebih mempengaruhi depresi seperti penggunaan skala selain dari Emotion Regulation Questionnaire (ERQ). Saran penelitian selanjutnya yaitu mempertimbangkan alat ukur Cognitive Emotion Regulation Questionnaire (CERQ) serta disarankan lebih memperhatikan kelengkapan kriteria subjek seperti usia, jenis kelamin, profesi subjek dan sebagainya. Kemudian penelitian Diponegoro et al. (2019) menyebutkan bahwa regulasi emosi kognitif akan berdampak baik tergantung dari aspek yang digunakan yaitu aspek adaptif khususnya dimensi cognitive reappraisal pada subjek yang merupakan mahasiswa Indonesia di Belanda dalam menghadapi permasalahan yang dikombinasikan dengan dimensi acceptance sehingga memunculkan emosi positif. Berdasarkan penelitian Diponegoro et al. (2019), bahwasanya peneliti ingin mengetahui apakah subjek mahasiswa Indonesia yang sedang mengerjakan tugas akhir di masa pandemi covid-19 akan serupa dalam menggunakan aspek adaptif atau sebaliknya maladaptif.

Perbedaan penelitian ini dengan penelitian sebelumnya yaitu menggunakan Cognitive Emotion Regulation Questionnaire (CERQ) yang lebih mengutamakan aspek kognitif dibandingkan Emotion Regulation Questionnaire (ERQ). Selain perbedaan skala, kriteria subjek juga dibedakan untuk melihat hasil pengaruh regulasi emosi kognitif terhadap depresi dari mahasiswa Indonesia tingkat akhir di situasi pandemi covid-19 yang sedang mengerjakan skripsi, hal ini karena masih belum adanya penelitian seperti di Belanda apakah mereka akan sama dalam mengatasi permasalahan dengan aspek adaptif atau sebaliknya yaitu maladaptif.

Berdasarkan pemaparan fenomena yang didukung beberapa referensi yang berkaitan, penelitian ini bertujuan untuk mengetahui seberapa besar pengaruh regulasi emosi kognitif terhadap depresi mahasiswa disituasi pandemi covid-19. Urgensi penelitian ini adalah untuk mencegah pemikiran bunuh diri seperti hasil Swaperiksa PDSKJI bahwa 1 dari 5 orang berfikir tentang hal tersebut, sehingga penelitian ini diharapkan dapat menunjukkan hasil penggunaan strategi regulasi kognitif apakah efektif atau kurang efektif pada kelompok dewasa awal khususnya mahasiswa yang sedang menempuh tugas akhir di masa pandemi. Kemudian untuk melihat aspek yang digunakan mahasiswa di Indonesia apakah aspek adaptif atau aspek maladaptif dalam mengatasi depresi saat mengerjakan tugas akhir di masa pandemi covid-19 sebagai bentuk evaluasi jika di masa depan saat terjadinya suatu fenomena serupa. Manfaat dari penelitian ini diharapkan memberikan kontribusi terhadap perkembangan kajian ilmu psikologi klinis serta sebagai sumber informasi dan gambaran bagi mahasiswa khususnya tingkat akhir mengenai regulasi emosi kognitif terhadap depresi dimasa pandemi covid19 agar lebih mampu mengelola emosi dan dijauhkan dari keputusan negatif seperti self-injury, penyalahgunaan narkoba, maupun bunuh diri.

\section{Depresi}

Berdasarkan DSM V (American Psychiatric Association, 2013) mendefinisikan depresi sebagai gangguan suasana perasaan dimana seseorang diliputi perasaan depresi seperti sedih, hampa, dan putus asa atau kehilangan minat dalam berbagai aktivitas selama 2 minggu atau lebih. Menurut Radloff (1977) depresi ditandai dengan adanya penurunan nafsu makan, suasana hati yang tertekan, munculnya perasaan bersalah dan rendahnya harga diri, tidak berharga dan putus asa, keterbelakangan psikomotorik, serta kualitas tidur yang kurang baik.

Depresi menurut King (dalam Al Aziz (2020)) disebabkan oleh faktor biologis, psikologis, dan sosial ekonomi. Faktor biologis berkaitan dengan gen yang diturunkan sehingga peluang depresi tidak jauh berbeda dengan orang tua. Faktor psikologis dipengaruhi oleh pengalaman yang dihadapi seseorang sehingga mempengaruhi pola pikir individu tersebut. Faktor sosial ekonomi dapat menyebabkan depresi ketika kurang sejahtera. Sedangkan menurut Kring et al. (2013) faktor yang menyebabkan depresi terdapat dua yaitu faktor psikologis dan faktor sosial. Faktor psikologis meliputi bagaimana proses berfikir seseorang dalam menanggapi permasalahan serta pengaruh seseorang dalam mengendalikan emosi yang tinggi. Kemudian faktor sosial berkaitan dengan peristiwa kehidupan yang mempengaruhi individu (life events) seperti kemampuan individu membangun komunikasi dengan individu maupun kelompok lainnya.

Simtom depresi menurut Radloff (1977) terdapat empat komponen yaitu Depressed effect ditandai dengan emosi negatif seperti sedih, depresi, kesepian, menangis; kedua Positive affect yaitu emosi positif individu seperti kebaikan, adanya harapan yang penuh, kebahagiaan, suka cita; ketiga yaitu Somatic symptoms adalah yang muncul pada penyakit mental menjadi penyakit fisik menyebabkan terganggunya nafsu makan, usaha menjalankan aktivitas sehari-hari lebih membutuhkan tenaga yang besar, permasalahan tidur yang kurang atau berlebihan, serta sulitnya menyelesaikan permasalahan dan memilih lari dari tanggungjawab; keempat yaitu hubungan interpersonal tidak ramah dan tidak suka terhadap perilaku orang lain terhadap individu yang mengalami depresi.

\section{Regulasi Emosi Kognitif}

Pengendalian emosi melalui pikiran atau kognitif membantu orang untuk mengelola emosi mereka saat mengalami peristiwa yang menyebabkan stress (Garnefski et al., 2001). Selanjutnya menurut Gross \& Jazaieri (2014) pengendalian emosi dapat berbagai macam baik secara intrinsik untuk mengatur emosi dalam diri maupun ekstrinsik yaitu merasakan ataupun mengatur emosi orang lain.

Faktor-faktor regulasi emosi kognitif menurut Ratnasari \& Suleeman (2017) pertama adalah usia, semakin bertambahnya usia menyebabkan banyaknya permasalahan yang dihadapi dan semakin baik dalam meregulasi emosi berdasarkan peristiwa hidupnya; kedua adalah 
keluarga, tiap anggota dalam mengatasi emosi menjadi suatu pola atau contoh bagi anggota lainnya; ketiga adalah lingkungan, secara nyata lingkungan pertemanan maupun media yang digunakan akan mempengaruhi emosi individu. Faktor kognitif Hasanah \& Widuri (2014) menyatakan bahwa kognitif mempengaruhi emosi dari cara penafsiran individu terhadap kejadian yang berkaitan dengan emosi.

Dimensi regulasi emosi kognitif menurut Garnefski et al. (2001) terdapat sembilan yang terbagi menjadi aspek adaptif dan aspek maladaptif. Aspek maladaptif terdiri dari: self blame, blaming others, rumination, catastrophizing; Aspek adaptif terdiri dari: putting into perspective, positive refocusing, positive reappraisal, acceptance, refocus on planning. Sembilan dimensi tersebut memiliki penjelasan sebagai berikut: (1) Self blame adalah menyalahkan diri sendiri, (2) Blaming others mengacu pada pikiran menyalahkan apa yang individu alami kepada orang lain, (3) Rumination atau perenungan yaitu memfokuskan diri pada pemikiran tentang perasaan dan berfikir dengan peristiwa negatif, (4) Catastrophizing mengacu pada pemikiran secara eksplisit menekan teror dari suatu pengalaman individu, (5) Putting into perspective adalah menempatkan ke dalam perspektif yang mengarah pada pemikiran mengecilkan keseriusan peristiwa atau menekan relativitas bila dibandingkan peristiwa lain, (6) Positive refocusing adalah pemfokusan ulang positif mengarah pada pemikiran hal-hal yang menyenangkan untuk mengalihkan pada kejadian pada realita, (7) Positive reappraisal adalah penilaian kembali yang positif mengacu pada pemikiran untuk memaknai secara positif pada peristiwa selama proses pertumbuhan individu, (8) Acceptance adalah penerimaan mengacu pada bagaimana individu dapat menerima dan menyerahkan diri apapun yang terjadi, dan (9) Refocus on planning merupakan perencanaan mengarah pada pemikiran untuk mengambil langkah-langkah ketika menghadapi peristiwa buruk.

Keterampilan pengendalian emosi akan berpengaruh pada kesehatan mental, jika ego semakin tinggi maka akan berdampak negatif seperti pendapat Aryaningsih \& Susilawati (2020) bahwa kemampuan untuk mengatur emosi negatif diperlukan untuk mengurangi dampak berbahaya yang muncul akibat konflik.

\section{Regulasi Emosi Kognitif dan Depresi}

Hasil penelitian pengaruh pelatihan keterampilan regulasi emosi baik kognitif serta perilaku terhadap penurunan depresi sejalan dengan hasil penelitian Compare et al. (2014) yaitu penggunaan strategi regulasi emosi kognitif yang adaptif (seperti penilaian kembali) memengaruhi pengurangan emosi stres dan pemulihan depresi, sebaliknya strategi regulasi emosi kognitif disfungsional (seperti perenungan dan penekanan emosi) berpengaruh dalam patogenesis depresi dan penyakit fisiologis.
Menurut Sakakibara \& Kitahara (2016) hasil yang didapatkan pada aspek menyalahkan diri sendiri, penerimaan, perenungan, bencana, dan menyalahkan orang lain memiliki korelasi yang positif dengan depresi maupun kecemasan. Sebaliknya aspek pemfokusan kembali pada perencanaan, penilaian ulang positif, dan penempatan ke dalam perspektif memiliki korelasi negative dengan depresi. Penyebab dari hasil penelitian ini yaitu data penelitian yang terbatas, perbedaan bahasa, ekspresi bahasa pada aitem, serta perbedaan budaya individu Jepang.

Berdasarkan penelitian yang telah disebutkan, terdapat perbedaan aspek regulasi emosi kognitif yang dapat mempengaruhi depresi salah satunya berdasarkan nilai budayanya. Pada penelitian di Indonesia nantinya diharapkan adanya pengaruh positif antara aspek-aspek regulasi emosi secara kognitif sebagai kemampuan mengendalikan emosi dalam menghadapi masalah pandemi serta mengerjakan tugas akhir yang dihadapi mahasiswa, sehingga menunjukkan penurunan depresi berdasarkan pengukuran skala yang digunakan.

\section{Hipotesis}

Terdapat pengaruh regulasi emosi kognitif terhadap depresi mahasiswa akhir dimasa pandemi covid-19. Semakin tinggi regulasi emosi kognitif maka semakin rendah depresi.

\section{Metode}

Penelitian ini menggunakan pendekatan kuantitatif. Proses pendekatan ini dimulai dari pengumpulan berupa data kuantitatif kemudian diolah menggunakan teknik statistik. Jenis penelitian yang digunakan adalah korelasional. Jenis penelitian ini berfungsi untuk melihat hasil penelitian tinggi atau rendahnya hubungan antar variabel.

\section{Subjek Penelitian}

Menurut Priyono (2008) populasi adalah keseluruhan satuan yang ingin diteliti. Teknik pengambilan sampel yang digunakan yaitu accidental sampling, merupakan teknik pengambilan sampel secara kebetulan berdasarkan karakteristik yang sudah ditentukan. Populasi penelitian merupakan mahasiswa akhir Diploma 3, Diploma 4, S1, serta S2 yang sedang mengerjakan tugas akhir, skripsi, maupun tesis di Indonesia pada masa pandemi covid-19. Usia yang dipilih merupakan dewasa awal berkisar 20-29 tahun berjenis kelamin laki-laki maupun perempuan, dan minimal sudah dalam 1 semester dalam proses pengerjaan skripsi. Jumlah subjek penelitian mengikuti kriteria tabel Isaac yang menunjukkan jika subjek jumlahnya tak terhingga dalam taraf signifikan mengikuti bidang sosial hukum 5\%, maka sampel yang diambil sebesar 349 orang.

\section{Variabel dan Instrumen Penelitian.}

Pada penelitian ini terdapat dua variabel yaitu satu variabel bebas $(\mathrm{X})$ dan satu variabel terikat $(\mathrm{Y})$. Variabel bebas 
pada penelitian ini adalah regulasi emosi kognitif (X), sedangkan variabel terikatnya adalah depresi (Y).

Depresi mencakup adanya empat komponen yaitu pengaruh Depressed effect ditandai dengan emosi negatif seperti sedih, depresi, kesepian, menangis; kedua Positive affect yaitu emosi positif individu seperti kebaikan, adanya harapan yang penuh, kebahagiaan, suka cita; ketiga yaitu Somatic symptoms adalah yang muncul pada penyakit mental menjadi penyakit fisik menyebabkan terganggunya nafsu makan, usaha menjalankan aktivitas sehari-hari lebih membutuhkan tenaga yang besar, permasalahan tidur yang kurang atau berlebihan, serta sulitnya menyelesaikan permasalahan dan memilih lari dari tanggungjawab; keempat yaitu hubungan interpersonal tidak ramah dan tidak suka terhadap perilaku orang lain terhadap individu yang mengalami depresi. Depresi diukur dengan alat ukur CES-D (Center for Epidemiologic Studies Depression Scale) milik Radloff (1977) yang diadaptasi oleh Kusuma (2011) sejumlah 20 aitem.

Regulasi mencakup adanya (1) Aspek maladaptif terdiri dari: self blame (menyalahkan diri sendiri); blaming others (menyalahkan orang lain); rumination (perenungan menganggap peristiwa negatif); catastrophizing (menekan pengalaman tidak menyenangkan); (2) Aspek adaptif terdiri dari: putting into perspective (menempatkan ke dalam perspektif); positive refocusing (pemfokusan ulang positif); positive reappraisal (penilaian kembali yang positif); acceptance (penerimaan); refocus on planning (fokus kembali pada perencanaan). Regulasi emosi kognitif diukur dengan alat ukur CERQ (Cognitive Emotion Regulation Questionnaire) milik Garnefski et al. (2001) yang diadaptasi oleh Prastuti et al. (2020). Jumlah aitem pada skala internasional milik Garnefski et al. (2001) terdapat 36 aitem, namun hasil adaptasi versi Indonesia menyatakan bahwa terdapat aitem yang memiliki kesamaan makna sehingga hasil akhir menjadi 17 aitem dari 9 aspek.

Kedua alat ukur menggunakan skala likert. Skala CES$D$ memiliki pilihan jawaban: Tidak Pernah (TP) bila hanya merasakan kurang dari 1 hari atau tidak sama sekali dalam 1 minggu terakhir, Jarang (J) bila merasakan 12 hari dalam 1 minggu terakhir, Kadang-kadang (KK) bila merasakan 3-4 hari dalam 1 minggu terakhir, Sering (S) bila merasakan 5-7 hari dalam 1 minggu terakhir. Sedangkan Skala CERQ memiliki pilihan jawaban: Selalu (S), Sering (SR), Kadang-kadang (KK), Jarang (J), Tidak Pernah (TP).

\section{Prosedur dan Analisis Data}

Penelitian yang dilakukan memiliki prosedur yaitu sebagai berikut: Persiapan merupakan tahapan utama melalui pencarian data sebagai pendukung fenomena berupa penelitian yang berkaitan. Setelah pencarian fenomena dan data adalah pengajuan judul serta diskusi kerangka penelitian kepada pembimbing satu. Melanjutkan kerangka dengan penyusunan teori dan instrumen penelitian dari berbagai referensi untuk penyusunan proposal yang didiskusikan dengan pembimbing dua. Tahap berikutnya yaitu dengan melakukan penyebaran instrumen kepada subjek yaitu uji try-out untuk menguji reliabilitas instrumen penelitian yang telah ditentukan melalui sosial media berbentuk google form selama 1 bulan dengan jumlah subjek yang didapatkan sebanyak 49 subjek.

Setelah mendapatkan data try-out, peneliti menguji reliabilitas instrumen menggunakan aplikasi SPSS 26 dengan hasil valid dan reliabel secara keseluruhan untuk instrumen $C E R Q$, sedangkan instrumen $C E S-D$ reliabel namun terdapat 1 aitem yang tidak valid yaitu aitem nomer 8 sehingga peneliti mengetahui aitem yang tidak diikutsertakan nantinya saat analisis data pada data final. Setelah itu peneliti menyerahkan hasil kepada dosen untuk dikoreksi dan meminta persetujuan turun lapang pengambilan data final. Setelah mendapatkan perijinan data final, peneliti menyalin isian kuesioner terbaru untuk disebarkan ke subjek yang memenuhi kriteria melalui media sosial twitter, telegram, instagram, facebook, serta tidak lupa melalui orang-orang terdekat. Proses pengumpulan data berkisar selama kurang lebih 2 bulan. Proses ini dilakukan dengan cara menyebarkan melalui postingan, bertukar pengisian kuesioner kepada responden yang memiliki kriteria yang sesuai dengan penelitian, perizinan kepada akun fanbase untuk ijin membantu penyebaran dan pengisian kuesioner. Setelah mendapatkan 420 subjek, peneliti melakukan seleksi terhadap data yang memiliki data ganda maupun yang tidak masuk ke dalam kriteria hingga menjadi 349 subjek. Kemudian peneliti melakukan koding yang berkaitan dengan pernyataan favourable dan unfavourable sesuai penelitian.

Setelah itu peneliti memproses data menggunakan aplikasi SPSS dengan tahapan uji korelasi, uji normalitas, uji linier sebagai syarat yang harus dipenuhi sebelum uji regresi sederhana. Setelah menguji hingga uji regresi, peneliti melaksanakan penulisan bab 4 dan 5 yang kemudian melakukan cek validasi data kepada laboratorium dan dinyatakan lulus. Setelahnya penulis menyerahkan kepada pembimbing untuk tahap bimbingan mengenai hasil yang didapatkan. Setelahnya penulis mendapatkan persetujuan dari kedua pembimbing, peneliti melakukan uji plagiasi kepada laboratorium.

\section{Hasil}

\section{Data Deskriptif}

Sebelum melakukan penelitian, peneliti menguji coba skala kepada 49 subjek untuk mengukur validitas dan reliabilitas. Hasil yang didapatkan yaitu skala $C E R Q$ nilai daya beda itemnya sebesar $0.310-0.700$ dan nilai reliabilitas sebesar 0.865 . Skala $C E S$ - $D$ terdapat item gugur pada nomer 8(0.149) sehingga setelah digugurkan nilai validitasnya sebesar $0.373-0.833$ dan nilai reliabilitasnya sebesar 0.898 . 
Tabel 1. Deskripsi Subjek Penelitian

\begin{tabular}{lll}
\hline Kategori & Frekuensi & Presentase \\
\hline $\begin{array}{l}\text { Jenis Kelamin } \\
\text { Laki-laki }\end{array}$ & 41 & 12 \\
Perempuan & 308 & 88 \\
Usia & & \\
20 & 51 & 15 \\
21 & 127 & 36 \\
22 & 135 & 39 \\
23 & 34 & 10 \\
24 & 2 & 1 \\
Pendidikan & & \\
Diploma 3 & 19 & 5 \\
Diploma 4 & 15 & 4 \\
Strata 1 & 312 & 89 \\
Strata 2 & 3 & 1 \\
\hline
\end{tabular}

Berdasarkan data yang telah didapatkan di lapangan terdapat 420 subjek, kemudian melalui seleksi data yang disebabkan adanya subjek yang tidak sesuai dengan kriteria pada metode penelitian menjadi 349 subjek. Pada Tabel 1 dipaparkan subjek penelitian yang digunakan.

Penelitian ini terdapat 2 variabel yaitu regulasi emosi kognitif sebagai variabel independen (X) dan variabel depresi sebagai variabel dependen (Y). Regulasi emosi kognitif memiliki mean sebesar $57.982(\mathrm{SD}=7.705)$ dengan skor minimum 37 dan maksimum 85. Sedangkan variabel depresi memiliki mean sebesar 25.002 (SD = 10.748) dengan nilai minimum 0 dan maksimum 53.

Dari hasil uji korelasi antar variabel menggunakan Product Moment Pearson didapatkan nilai koefisien yang signifikan 0.000 dimana apabila $(\mathrm{p}<0.05)$ maka data tersebut memiliki korelasi/hubungan. Pada nilai pearson correlation sebesar 0.204 menandakan adanya hubungan positif antara variabel regulasi emosi kognitif dan variabel depresi.

\section{Hasil Analisa}

Hasil uji normalitas penelitian menggunakan nilai kolmogorov-smirnov $=0.043$ dengan nilai Sig. sebesar 0.200 . Berdasarkan uji normalitas maka data penelitian ini dapat dikatakan telah berdistribusi normal.

Setelah uji normalitas diketahui berdistribusi normal, maka langkah selanjutnya adalah uji linieritas antara variabel regulasi emosi kognitif dan depresi. Hasil uji linieritas menghasilkan nilai $\mathrm{F}=14.803$ dengan nilai sig. 0.000. Apabila nilai sig $<0.050$, maka antara regulasi emosi kognitif dan depresi dapat dikatakan linier.

Pada Tabel 2 terlihat hasil uji analisis regresi sederhana yang dilakukan dengan uji $\mathrm{F}$ bertujuan untuk melihat pengaruh dari variabel bebas $(\mathrm{X})$ yaitu regulasi emosi kognitif terhadap variabel terikat (Y) yaitu depresi. Hasil uji regresi nilai $\mathrm{F}=15.129$ dengan nilai sig sebesar 0.000 . Jika sig $<0.050$, maka artinya adanya pengaruh antara variabel X dan Y. Dalam penelitian ini nilai sig sebesar
0.000 yang mengartikan bahwa adanya pengaruh yang signifikan antara regulasi emosi kognitif terhadap depresi.

Besaran pengaruh dalam uji regresi dapat dilihat pada nilai $R$ square sebesar 0.042 , jika diubah dalam prosentase yaitu setara dengan $4.2 \%$, sedangkan sisanya 0.958 atau $95.8 \%$ berasal dari variabel selain regulasi emosi kognitif serta faktor lainnya.

Persamaan regresi penelitian ini yaitu $y=15.129+$ $0.285 X$, yang memiliki arti apabila mahasiswa tingkat akhir tidak memiliki regulasi emosi kognitif, maka mereka mereka masih memiliki depresi sebesar 15.129. Setiap penambahan 1 poin regulasi emosi kognitif pada mahasiswa tingkat akhir akan mengalami peningkatan depresi sebesar 0.285 .

Kesimpulan dari hasil analisa dapat dikatakan regulasi emosi kognitif memiliki pengaruh yang signifikan terhadap depresi pada mahasiswa tingkat akhir di masa pandemi covid-19 sebesar 4.2\%. Hipotesis pada penelitian ini ditolak karena variabel $\mathrm{X}$ berpengaruh positif yang signifikan terhadap variabel $\mathrm{Y}$, yakni apabila semakin tinggi regulasi emosi kognitif tinggi yang dimiliki mahasiswa, maka semakin tinggi pula depresi mereka dalam menghadapi tugas akhir di masa pandemi covid-19.

\section{Diskusi}

Berdasarkan latar belakang pada penelitian ini bahwasanya pandemi covid-19 memiliki berbagai dampak diberbagai sektor khususnya pendidikan. Data Swaperiksa PDSKJI (Perhimpunan dokter spesialis kedokteran jiwa Indonesia) dimasa pandemi covid-19 menyatakan bahwa terdapat kelompok usia yang mengalami depresi yaitu kelompok usia 17-29 tahun sebesar 66.3\%, kemudian muncul beberapa penelitian mengenai depresi banyak dialami oleh mahasiswa tingkat akhir dimasa pandemi seperti penelitian Universitas Airlangga mendapatkan data usia 22-23 mengalami depresi sedang sebesar $22.46 \%$, usia 20-21 tahun mengalami depresi tinggi sejumlah 57.22\% dibandingkan usia 18-19 tahun yang mengalami depresi paling rendah sejumlah $20.32 \%$ (Prayogi et al., 2020). Landasan lainnya adalah berupa penelitian Farahdika \& Listiyandini (2018) menduga adanya faktor lain yang lebih mempengaruhi depresi seperti penggunaan skala selain dari Emotion Regulation Questionnaire (ERQ) pada segi kognitif dengan dimensi cognitive reappraisal dan expressive suppression. Oleh karena itu tujuan penelitian ini berfokus untuk melihat pengaruh dari regulasi emosi beraspek kognitif yaitu Cognitive Emotion Regulation Questionnaire (CERQ) terhadap depresi mahasiswa tingkat akhir di masa pandemi covid19 yang dilakukan di wilayah Indonesia.

Berdasarkan penelitian yang dilakukan, ditemukan adanya pengaruh yang signifikan antara variabel regulasi emosi kognitif terhadap variabel depresi dengan $\mathrm{F}$ hitung $=$ 15.129 nilai sig. sebesar 0.000 yang mengartikan hipotesis penelitian ditolak karena korelasinya positif. Hal ini berarti bahwa semakin tinggi regulasi emosi kognitif mahasiswa 
Tabel 2. Uji Regresi Sederhana

\begin{tabular}{|c|c|c|c|c|c|c|c|c|}
\hline & \multicolumn{2}{|c|}{ Unstandardized coeficient } & \multicolumn{3}{|c|}{ Standardized coeficient } & \multirow[b]{2}{*}{$\mathrm{F}$} & \multirow[b]{2}{*}{$\mathrm{R}$} & \multirow[b]{2}{*}{$R^{2}$} \\
\hline & $\mathrm{B}$ & SE & beta & $\mathrm{t}$ & $\mathrm{p}$ & & & \\
\hline Constant & 8.469 & 4.288 & & 1.975 & .049 & \multirow{2}{*}{15.129} & \multirow{2}{*}{.204} & \multirow{2}{*}{.042} \\
\hline Regulasi Emosi Kognitif & .285 & .073 & .204 & 3.890 & .000 & & & \\
\hline
\end{tabular}

Catatan : Depresi $(\mathrm{Y})$

tingkat akhir, maka semakin tinggi depresi mereka di masa pandemi covid-19.

Penyebab korelasi tidak sesuai dengan hipotesa awal dikarenakan banyaknya subjek di variabel regulasi emosi kognitif lebih menggunakan aspek maladaptif pada dimensi rumination yang lebih tinggi dengan poin rata-rata 1363 dibandingkan aspek adaptif pada dimensi positive reappraisal sebesar 1172 serta pada dimensi putting into perspective sebesar 1211. Hal ini membuktikan bahwa dimensi positive reappraisal memiliki hasil yang sama yaitu nilai kurang berpengaruh seperti pada penelitian Farahdika \& Listiyandini (2018) yang dapat menyebabkan melemahnya aspek adaptif. Hasil ini didukung pula dengan penelitian Mohammadzadeh-Ebrahimi \& RahimiPordanjani (2017) bahwa individu yang menggunakan strategi regulasi emosi kognitif adaptif untuk tingkat lebih besar setelah mengalami peristiwa hidup yang penuh tekanan menunjukkan hasil depresi yang lebih sedikit. Sebaliknya individu yang menggunakan strategi maladaptif lebih rendah menunjukkan depresi lebih tinggi.

Pada penelitian ini digambarkan arah hubungan positif lebih dominan dibandingkan arah negatif, sehingga uji korelasi menunjukkan ke arah positif bagi mahasiswa tingkat akhir di masa pandemi covid-19. Penelitian ini didukung oleh penelitian Domaradzka \& Fajkowska (2018) menyatakan bahwa terdapat hubungan yang berada di arah yang diharapkan (signifikan), strategi regulasi emosi kognitif memiliki dua arah hubungan yaitu untuk aspek maladaptif (self blame, blaming others, rumination, catastrophizing) berhubungan positif, namun untuk aspek adaptif (putting into perspective, positive refocusing, positive reappraisal, acceptance, refocus on planning) berada pada hubungan negatif terhadap kecemasan dan depresi.

Penelitian Mariani et al. (2021) menyatakan lockdown pandemi covid-19 mempengaruhi regulasi emosi kognitif dan sistem emosi primer secara relevan yang menyebabkan depresi, kecemasan, obsesif kompulsif pada $30 \%$ peserta. Khususnya pada regulasi emosi kognitif selama lockdown menyebabkan penurunan penilaian ulang positif karena peserta mengalami depresi, kecemasan, serta obsesif kompulsif dibanding sebelum adanya pandemi covid19. Hal ini menyatakan bahwasanya regulasi emosi kognitif melemah khususnya penilaian ulang positif yang termasuk dalam aspek adaptif menyebabkan menguatnya aspek maladaptif sehingga peserta mengalami peningkatan depresi, kecemasan, dan obsesif kompulsif karena adanya pandemi covid-19 dan perlunya waktu lebih lama dalam pemulihan pasca pandemi.

Nilai kontribusi regulasi emosi kognitif terhadap depresi yakni sebesar $4.2 \%$. Prosentase sebesar $95.8 \%$ penyebab depresi khususnya pada mahasiswa di masa pandemi bisa dipengaruhi dari faktor selain regulasi emosi kognitif. Penelitian Prayogi et al. (2020) mengemukakan faktor depresi dapat disebabkan oleh usia yang memiliki tingkat pengaruh $82.1 \%$, jenis kelamin $85.9 \%$, serta angkatan tahun kuliah $68.4 \%$. Selain itu penelitian Purnomo et al. (2020) menyatakan faktor mahasiswa di masa pandemi mengalami depresi karena adanya rasa kesepian kategori tinggi 33\%, kategori agak tinggi 23\%, kategori sedang $17 \%$, dan kategori rendah $4.3 \%$.

Setiap penelitian pasti adanya kelebihan dan keterbatasannya. Adapun kelebihan penelitian ini dapat dijadikan acuan informasi mahasiswa maupun pendidik untuk lebih memperhatikan psikologis di masa pandemi maupun sebagai persiapan di masa yang akan datang dengan meningkatkan kemampuan regulasi emosi kognitif pada aspek adaptif untuk menurunkan depresi. Keterbatasan penelitian ini adalah tidak menghubungkan riwayat memiliki gangguan psikologis sehingga harapannya untuk peneliti selanjutnya dapat mencantumkan riwayat masalah psikologis subjek seperti bipolar, skizofrenia, depresi mayor, insomnia, dan lain sebagainya agar bisa memberikan perbedaan dipenelitian berikutnya.

\section{Kesimpulan}

Penelitian ini memiliki hasil regulasi emosi kognitif berpengaruh signifikan terhadap depresi mahasiswa tingkat akhir di masa pandemi covid-19 dengan arah hubungan positif sehingga apabila regulasi emosi kognitif meningkat maka depresi meningkat pula. Penyebab peningkatan depresi ini dikarenakan adanya penurunan regulasi emosi kognitif dalam aspek adaptif pada dimensi positive reappraisal dan dimensi putting into perspective dimasa pandemi. Prosentase pengaruh regulasi emosi kognitif terhadap depresi yakni sebesar $4.2 \%$, sisanya sebesar $95.8 \%$ dapat berasal dari faktor selain dari regulasi emosi kognitif. Bagi peneliti selanjutnya bisa menggunakan faktor-faktor tambahan dan lebih memperhatikan kriteria riwayat fisik atau psikologis subjek di Indonesia untuk mendapatkan perbedaan dipenelitian berikutnya. 


\section{Referensi}

Al Aziz, A.A. (2020). Hubungan antara intensitas penggunaan media sosial dan tingkat depresi pada mahasiswa. Acta Psychologia, 2(2), 92-107. https://doi.org/10.21831/ap.v2i2. 35100

American Psychiatric Association. (2013). Diagnostic and Statistical Manual of Mental Disorders, 5th Edition: DSM5. Arlington, VA: American Psychiatric Publishing,

Aryaningsih, P.I.A., \& Susilawati, L.K.P.A. (2020). Peran intensitas komunikasi dan regulasi emosi terhadap konflik interpersonal pada dewasa awal yang menjalani hubungan berpacaran jarak jauh. Jurnal Psikologi Udayana, 7(1), 20-30. https://ojs.unud.ac.id/index.php/psikologi/article/ download/57759/34471

Compare, A., Zarbo, C., Shonin, E., Van Gordon, W., \& Marconi, C. (2014). Emotional regulation and depression: A potential mediator between heart and mind. Cardiovascular psychiatry and neurology, 2014, 1-10. http://dx.doi.org/10.1155/2014/ 324374

Diponegoro, A.M., Ru’ya, S., \& Dewi, L. (2019, November). Cognitive reappraisal muslim Indonesia di Belanda. Prosiding Seminar Nasional Magister Psikologi Universitas Ahmad Dahlan (pp. 476-484). http://seminar.uad.ac.id/index. php/snmpuad/article/view/3463

Domaradzka, E., \& Fajkowska, M. (2018). Cognitive emotion regulation strategies in anxiety and depression understood as types of personality. Frontiers in psychology, 9, 856. https: //doi.org/10.3389/fpsyg.2018.00856

Doré, B. P., Morris, R. R., Burr, D. A., Picard, R. W., \& Ochsner, K. N. (2017). Helping others regulate emotion predicts increased regulation of one's own emotions and decreased symptoms of depression. Personality and Social Psychology Bulletin, 43(5), 729-739. https://doi.org/10.1177/ 0146167217695558

Mohammadzadeh-Ebrahimi, A., \& Rahimi-Pordanjani, T. (2017). The moderating role of cognitive emotion regulation strategies in the relationship between stressful events and depression symptoms. Journal of Research in Behavioural Sciences, 15(2), 213-220. http://rbs.mui.ac.ir/article-1-534-en.html

Farahdika, T., \& Listiyandini, R. A. (2018). Peran Strategi Regulasi Emosi Terhadap Gejala Depresi Pada Remaja Dengan Orangtua Bercerai. In Seminar Nasional dan Temu Ilmiah Positive Psikologi (pp. 248-258).

Gao, J., Zheng, P., Jia, Y., Chen, H., Mao, Y., Chen, S., \& Dai, J. (2020). Mental health problems and social media exposure during COVID-19 outbreak. Plos one, 15(4), e0231924. https://doi.org/10.1371/journal.pone.0231924

Garnefski, N., Kraaij, V., \& Spinhoven, P. (2001). Negative life events, cognitive emotion regulation and emotional problems. Personality and Individual differences, 30(8), 1311-1327. https://doi.org/10.1016/S0191-8869(00)00113-6

Gross, J. J., \& Jazaieri, H. (2014). Emotion, emotion regulation, and psychopathology: An affective science perspective. Clinical psychological science, 2(4), 387-401. https://doi. org/10.1177/2167702614536164

Hanaysha, J. (2016). Testing the effects of employee empowerment, teamwork, employee training on employee productivity in higher education sector. International Journal of Learning and Development, 6(1), 164-178. https://doi.org/ 10.5296/ijld.v6il.9200

Hasanah, T.D.U., \& Widuri, E.L. (2014). Regulasi emosi pada ibu single parent. Jurnal Psikologi Integratif, 2(1), 86-92. https://doi.org/10.14421/jpsi.2014.\%25x

Herman, H., \& Jané-Llopis, E. (2005). Mental health promotion in public health. Promotion \& Education, 12(2), 42-47. https: //doi.org/10.1177/10253823050120020107

Joorman, J., \& Gotlib, I.H. (2010). Emotion regulation in depression: Regulation to cognitive inhibition. Cognitive and Emotion, 24(2), 281-298. https://doi.org/10.1080/ 02699930903407948

Kring, A. M., Gur, R. E., Blanchard, J. J., Horan, W. P., \& Reise, S. P. (2013). The clinical assessment interview for negative symptoms (CAINS): final development and validation. American journal of psychiatry, 170(2), 165-172. https://doi.org/10.1176/appi.ajp.2012.12010109

Kurniati, N.I., Mubarok, H., \& Reinaldi, A. (2017). Rancang bangun sistem pakar diagnose tingkat depresi pada mahasiswa tingkat akhir menggunakan metode fuzzy tsukamoto (Studi kasus: Universitas Siliwangi). Jurnal Online Informatika, 2(1), 49-55. https://doi.org/10.15575/ join.v2i1.87

Kusuma, H. (2011). Hubungan antara depresi dan dukungan keluarga dengan kualitas hidup pasien HIV/AIDS yang menjalani perawatan di RSUPN Cipto Mangunkusumo Jakarta (Unpublished doctoral dissertation). Fakultas Psikologi Universitas Indonesia, Depok.

Mariani, R., Renzi, A., Di Monte, C., Petrovska, E., \& Di Trani, M. (2021). The Impact of the COVID-19 Pandemic on Primary Emotional Systems and Emotional Regulation. International Journal of Environmental Research and Public Health, 18(11), 5742. https://doi.org/10.3390/ ijerph18115742

Moreno, C., Wykes, T., Galderisi, S., Nordentoft, M., Crossley, N., Jones, N., \& Arango, C. (2020). How mental health care should change as a consequence of the COVID-19 pandemic. The Lancet Psychiatry 7(9), 813-24. https://doi.org/10.1016/ S2215-0366(20)30307-2

Munadliroh, N.H., \& Faizah, S.N. (2020). Peran guru dalam pembelajaran daring di era pandemic covid-19. Jilid 1. Edisi 1. Lamongan: Litbang Permas Unissula.

PDSKJI.org. (2020, Agustus). Depresi, bunuh diri, dan pandemi covid-19. Diakses pada 3 Desember 2020, dari http://pdskji.org/home

Prastuti, E., Tairas, M.M.W., \& Hartini, N. (2020). Adaptation and validation of cognitive emotion regulation questionnaire (CERQ) in Indonesian version. Journal of Educational Health and Community Psychology, 9(2), 132-147. http://dx. doi.org/10.12928/jehcp.v9i2.14668 
Prayogi, A.R.I.Y., Hardini, P.P., Alamiyyah, M., Sari, K.I., Haqi, D.N., \& Sari, J.D. (2020). Pengaruh antara faktor determinan terhadap tingkat depresi mahasiswa dimasa pandemi (Universitas Airlangga Surabaya). Journal of Community Mental Health and Public Policy, 2(2), 1-9. https: //doi.org/10.51602/cmhp.v2i2.42

Priyono. (2008). Metode penelitian kuantitatif. Sidoarjo: Zifatama Publishing.

Purnomo, A.W.A., Dwijayanti, M.D., \& Sabtana, F. I. (2020). Gambaran tingkat kesepian dan depresi mahasiswa bimbingan dan konseling selama pembelajaran daring. Consilia : Jurnal Ilmiah Bimbingan dan Konseling, 3(3), 199-207. https://ejournal.unib.ac.id/index.php/j\$_\$consilia

Radloff, L.S. (1977). The CES-D scale: A self-report depression scale for research in the general population. Applied psychological measurement, 1(3), 385-401. https://doi.org/ $10.1177 / 014662167700100306$

Ratnasari, S., \& Suleeman, J. (2017). Perbedaan regulasi emosi perempuan dan laki-laki di perguruan tinggi. Jurnal Psikologi Sosial, 15(1), 35-46. https://doi.org/10.7454/jps. 2017.4

Rejo, Arandini, D., Darmayanti, A.T., Widiyanto, A., \& Atmojo, J.T (2020). Faktor-faktor yang berhubungan dengan depresi pada tenaga kesehatan saat pandemic covid-19. Jurnal Ilmu Keperawatan Jiwa, 4(3), 495-502.
Rodriguez, L. M., Lee, K. D., Onufrak, J., Dell, J. B., Quist, M., Drake, H. P., \& Bryan, J. (2020). Effects of a brief interpersonal conflict cognitive reappraisal intervention on improvements in access to emotion regulation strategies and depressive symptoms in college students. Psychology \& health, 35(10), 1207-1227. https: //doi.org/10.1080/08870446.2019.1711090

Sakakibara, R., \& Kitahara, M. (2016). The relationship between cognitive emotion regulation questionnaire (CERQ) and depression, anxiety: Meta-analysis. The Japanese Journal of Psychology, 87(2), 179-185. https://doi.org/10.4992/jjpsy.87. 15302

Santoso, A., Ardi, W. R., Prasetya, R. L., Dwidiyanti, M., Wijayanti, D. Y., Mu'in, M., \& Aisah, N. A. (2020). Tingkat depresi mahasiswa keperawatan di tengah wabah COVID19. Holistic Nursing and Health Science, 3(1), 1-8. https: //doi.org/10.14710/hnhs.3.1.2020.1-8

Santrock, J.W. (2002). Perkembangan rentang hidup. Jilid 2. Jakarta: Erlangga.

Saputri, I.A., \& Nurrahim, A. (2020). Faktor-faktor yang mempengaruhi depresi anak usia sekolah: Kajian literature. Holistic Nursing and Health Science, 3(2), 50-58. https://doi. org/10.14710/hnhs.3.2.2020.50-58

Siswoyo, D. (2007). Ilmu pendidikan. Yogyakarta: UNY Press.

Tian, F., Li, H., Tian, S., Yang, J., Shao, J., \& Tian, C. (2020). Psychological symptoms of ordinary Chinese citizens based on SCL-90 during the level I emergency response to COVID19. Psychiatry research, 288, 112992. https://doi.org/10. 1016/j.psychres.2020.112992 